\title{
Lifelong \\ Learning Policies for Young Adults in Europe
}

Navigating between

Knowledge and Economy

\section{Edited by}

Marcelo Parreira do Amaral,

Siyka Kovacheva, Xavier Rambla

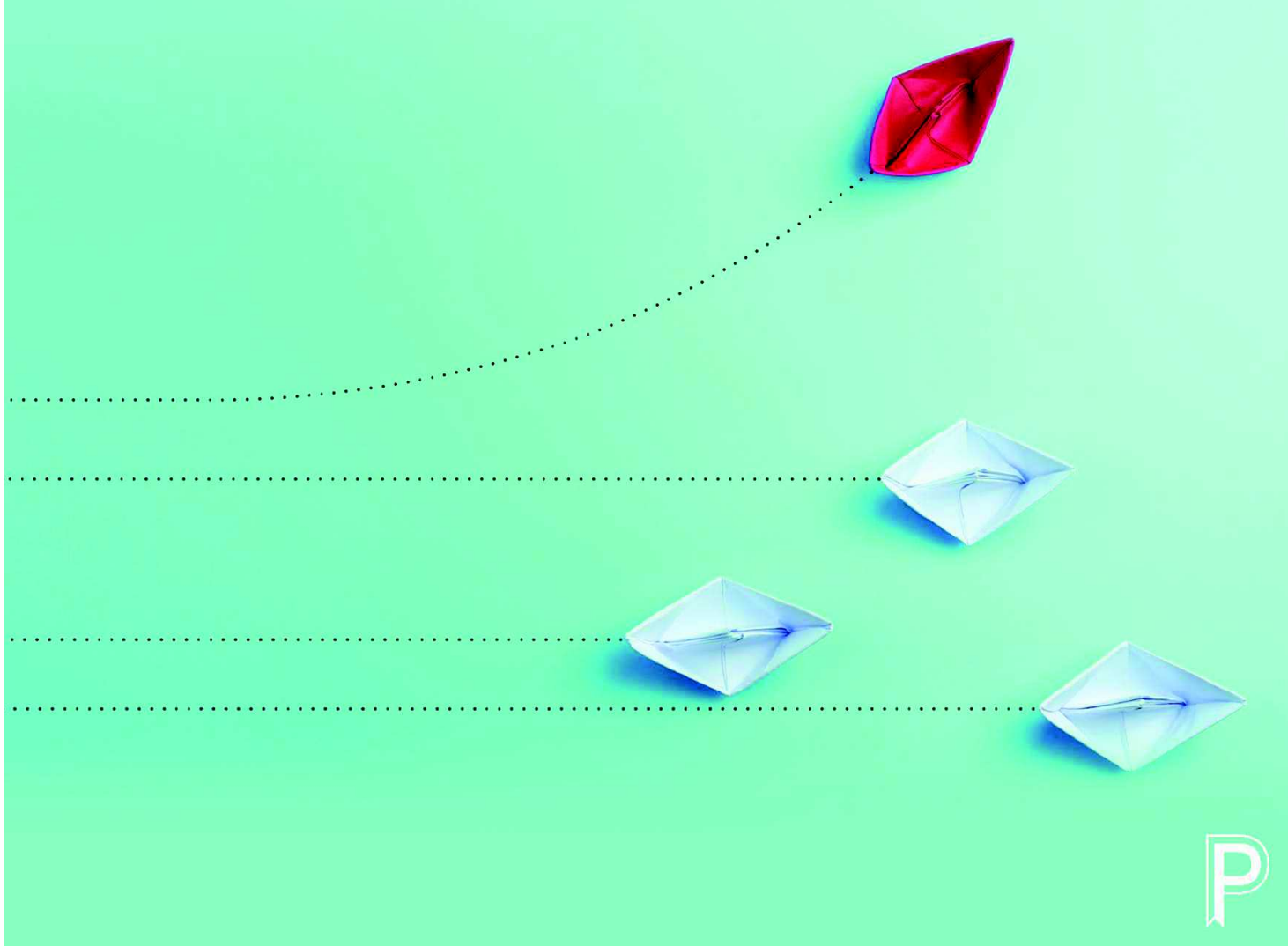




\title{
LIFELONG LEARNING POLICIES FOR YOUNG ADULTS IN EUROPE \\ Navigating between Knowledge and Economy
}

\author{
Edited by \\ Marcelo Parreira do Amaral, Siyka Kovacheva \\ and Xavier Rambla
}




\author{
Policy Press \\ University of Bristol \\ 1-9 Old Park Hill \\ Bristol \\ BS2 8BB \\ UK \\ t: +44 (0)1179545940 \\ pp-info@bristol.ac.uk \\ www.policypress.co.uk
}

\author{
North America office: \\ Policy Press \\ c/o The University of Chicago Press \\ 1427 East 60th Street \\ Chicago, IL 60637, USA \\ t: +17737027700 \\ f: +1 773-702-9756 \\ sales@press.uchicago.edu \\ www.press.uchicago.edu
}

\section{(C) Policy Press 2020}

The digital PDF version of this title is available Open Access and distributed under the terms of the Creative Commons Attribution-NonCommercial 4.0 license (http://creativecommons. org/licenses/by-nc/4.0/) which permits adaptation, alteration, reproduction and distribution for non-commercial use, without further permission provided the original work is attributed. The derivative works do not need to be licensed on the same terms.

British Library Cataloguing in Publication Data

A catalogue record for this book is available from the British Library

Library of Congress Cataloging-in-Publication Data

A catalog record for this book has been requested

ISBN 978-1-4473-5036-1 hardback

ISBN 978-1-4473-5066-8 ePdf

ISBN 978-1-4473-5067-5 ePub

The rights of Marcelo Parreira do Amaral, Siyka Kovacheva and Xavier Rambla to be identified as editors of this work has been asserted by them in accordance with the Copyright, Designs and Patents Act 1988

All rights reserved: no part of this publication may be reproduced, stored in a retrieval system, or transmitted in any form or by any means, electronic, mechanical, photocopying, recording, or otherwise without the prior permission of Policy Press.

The statements and opinions contained within this publication are solely those of the editors and contributors and not of the University of Bristol or Policy Press. The University of Bristol and Policy Press disclaim responsibility for any injury to persons or property resulting from any material published in this publication.

Policy Press works to counter discrimination on grounds of gender, race, disability, age and sexuality.

Cover design by Clifford Hayes

Front cover image: gettyimages

Printed and bound in Great Britain by CPI Group (UK) Ltd,

Croydon, CR0 4YY

Policy Press uses environmentally responsible print partners

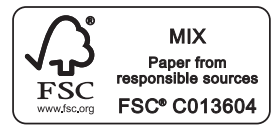




\section{Contents}

List of figures and tables $\quad \mathrm{V}$

Notes on contributors vii

Preface xiii

Introduction: $\quad$ xvii

Between knowledge and economy: lifelong learning policies

for young adults in Europe

Xavier Rambla, Siyka Kovacheva and Marcelo Parreira do Amaral

PART I: Lifelong learning between knowledge and economy

1 Lifelong learning policies for young adults in Europe:

a conceptual and methodological discussion

Marcelo Parreira do Amaral

2 Coordinated policy-making in lifelong learning: functional regions as dynamic units

Marcelo Parreira do Amaral, Kevin Lowden, Valeria Pandolfini and Nikolas Schöneck

3 A social investment perspective on lifelong learning: the role of institutional complementarities in the development of human capital and social participation Yuri Kazepov, Ruggero Cefalo and Mirjam Pot

PART II: Lifelong learning supporting young adults

$4 \quad$ Young adults as a target group of lifelong learning policies Xavier Rambla, Dejana Bouillet and Borislava Petkova

5 The effectiveness of lifelong learning policies on youth employment: do regional labour markets matter? Queralt Capsada-Munsech and Oscar Valiente

6 Governing the normalisation of young adults through lifelong learning policies Risto Rinne, Heikki Silvennoinen, Tero Järvinen and Jenni Tikkanen

$7 \quad$ Tackling vulnerability through lifelong learning policies? Thomas Verlage, Valentina Milenkova and Ana Bela Ribeiro 
$8 \quad$ Are lifelong learning policies working for youth?

Young people's voices

Siyka Kovacheva, Judith Jacovkis, Sonia Startari

and Anna Siri

PART III:Young adults' experiences of lifelong learning in the European Union

9 Assessing young adults' living conditions across Europe using harmonised quantitative indicators: opportunities and risks for policy makers

Rosario Scandurra, Kristinn Hermannsson and Ruggero Cefalo

10 The changing meanings of lifelong learning policies: consequences for young adults and their life courses Tiago Neves, Natália Alves, Anna Cossetta and Vlatka Domović

11 Telling the story: exploring lifelong learning policies for young adults through a narrative approach Mauro Palumbo, Sebastiano Benasso and Marcelo Parreira do Amaral

Conclusion:

Navigating lifelong learning policies in Europe: impacting and supporting young adults' life courses Siyka Kovacheva, Xavier Rambla and Marcelo Parreira do Amaral Index 


\section{PART I}

Lifelong learning between knowledge and economy 


\title{
Coordinated policy-making in lifelong learning: functional regions as dynamic units
}

\author{
Marcelo Parreira do Amaral, Kevin Lowden, \\ Valeria Pandolfini and Nikolas Schöneck*
}

\section{Introduction}

Most of our social reality - for instance, education, labour market or welfare statistical information - has traditionally been organised as 'national' phenomena. For this reason, since the 19th century, nation states have been traditionally considered the 'natural' units of analysis throughout social sciences research. However, with changing realities brought about by internationalisation, Europeanisation and globalisation processes among others, static and absolute concepts such as that of the nation state have been challenged with regard to their usefulness for explaining our social world. In international comparative research, more recently, the assumption that the implementation of lifelong learning (LLL) policies is best studied at the regional/local level encouraged a more differentiated examination than the national level allows. By adopting the concept of 'functional region' (FR), our research aimed at conceptually taking into account not only policies' administrative aspects but also their functional dynamics, their interrelations with other units as well as the interaction of different sectoral policies. This chapter argues that FRs provide a useful concept to understand differences in the coordination of policies at the regional/local level; they are thus key in understanding the embeddedness of LLL policies for young adults in the regional/local

\footnotetext{
* Although this chapter is the result of intense collaboration among all the authors, we would like to state that Valeria Pandolfini has contributed the section on 'Policy analysis across Europe's regions: accounting for different realities' and 'Policy analysis across Europe's regions in the YOUNG_ADULLLT project'.
} 
interplay between economy, society, the labour market and education and training systems.

In the sections that follow, the first explores the changing global context for policy-making and the implications - conceptual and methodological - for policy analysis. Second, the concept of FR is introduced as an approach that extends beyond the national and better accounts for different realities; this section also discusses different conceptualisations and types. In the third section, the units selected for research in the European YOUNG_ADULLLT project are presented, highlighting functional, and thus dynamic rather than administrative, units as research sites. In order to discuss the value-added and the challenges related to this conceptualisation, two FRs in Scotland are more closely examined before drawing more general conclusions as to the utility of the concept in supporting the formulation of coordinated policy-making in the field of LLL.

\section{Policy-making in a changing global context}

Contemporary societies have been heavily impacted by what have been termed internationalisation, Europeanisation and globalisation processes. As a buzzword, the term globalisation has been used to describe the major transformations taking place in modern societies since the early 1970s (Parreira do Amaral, 2014: 118). As a social scientific research topic, it prompted myriad understandings of changes associated with globalisation processes, the quality and pace of these transformations as well as of the implications for the social world. Following David Held and Anthony McGrew:

Globalization denotes the expanding scale, growing magnitude, speeding up and deepening impact of interregional flows and patterns of social interaction. It refers to a shift or transformation in the scale of human social organization that links distant communities and expands the reach of power relations across the world's major regions and continents. (2003: 4)

This understanding of globalisation is useful in calling attention to processes of re-spatialisation and rescaling of human activity, which constitute fundamental transformations in the organisation of social relationships. In terms of place and space, the argument is that increasingly social interaction and flows of people, products, symbols and information are no longer occurring in or between 
discrete and singular places but in places/spaces that are at once distinct and connected (Castree et al, 2013a, 2013b). In terms of scale, research focus has shifted to how the local, regional, national, international emerged in historical and social processes as 'platform[s] and container[s] [for] certain kinds of social activity' (Brenner, 2004a: 9). Thus, social, interactional and relational aspects may be seen as central in understanding globalisation processes and their relevance to policy-making.

The latter stands in contrast to policy analysis' traditionally privileged focus on the modern, territorial nation state and on what national 'governments choose to do or not to do' (Dye, 2017: 2). Policy analysis and its conceptual toolkit reflect the fundamental importance of the territorial nation state for the spatial organisation of human activity and public policy. This territoriality of the state, understood as 'claims to and forms of control over bounded spaces' (McCarthy, 2007: 959), was formally linked to the idea of sovereignty in the Peace of Westphalia. Until the late 20th century, the spatiality of human activity had been marked by processes of territorialisation, which established and cemented the nation state as an almost natural unit of analysis. Territorialisation refers to the 'organization of human activities by fixing them in spatial territory' (Castree et al, 2013c: np), resulting in a world divided into 'contiguous and nonoverlapping areas, each identified with a sovereign state' (McCarthy, 2007: 959). Within these respective territories, states became increasingly important agents in the organisation of human activity through an expanding repertoire of regulatory activities (military defence, economic wealth, cultural identity, political legitimation, social welfare; cf Brenner, 2004b). Taylor perceptively summarised the outcome of this, pointing to the 'container-like qualities' of the modern nation state (1994: 152). While the underlying notion of internal and external sovereignty was rarely achieved, the aforementioned processes of territorialisation resulted in the practice of using the nation state as basic unit of analysis when investigating policy-making. Public policy was seen as made by national governments and administrations and largely directed at the organisation of human activity within their 'own' respective territories.

Since the late 1990s, researchers have argued that this basic premise has become more and more inadequate as globalisation entails processes of both de-territorialisation and re-territorialisation (Brenner, 1999), rendering the relationship between state territoriality, sovereignty and power more complex. De-territorialisation refers to the decreasing significance of territory for organising human affairs in general 
and more specifically national borders. The extreme case of this development would be what Castells (2009) described as the network society, no longer a space of places, but a space of flows, detached from territory. Nonetheless, while 'powerful new non-territorial forms of economic and political organization in the global domain, such as multinational corporations, [and] transnational social movements' (Held et al, 1999: 9) emerged, territories remain important. However, the latter are being reshaped as the territorial and supraterritorial interact, resulting in processes of re-territorialisation (Brenner, 2004a), in which governments are strategic actors. These processes of de- and re-territorialisation entail significant implications for public policy analysis. Political communities can no longer be identified 'as simply discrete worlds or self-enclosed political spaces; they are enmeshed in complex structures of overlapping forces, relations and networks' (Held and McGrew, 2003: 41).

These processes of respatialisation and rescaling imply that policy analysis needs to acknowledge the national scale as but one of several. Depending on the issue, the nation state might continue to present itself as the most relevant context for analysis, but this should not be taken as the exclusive framework of study and analysis.

Departing from the discussion of this changed environment, the following section argues that policy analysis needs to take into account the different contexts in which policy formulation, decision-making and implementation take place. Against this background the potential of the concept of FRs as dynamic units in the development and analysis of LLL policy-making is subsequently discussed.

\section{Policy analysis across Europe's regions: accounting for different realities}

The assumption that LLL policies are best studied at the regional/local level invites us to take a more differentiated glance than the national level allows for. Likewise, departing from the principle of subsidiarity in European policy-making, accounting for regional variations becomes central as differences occur among locales not only within but also across countries. Thus, research needs to account for this high degree of complexity in its analyses in order to provide accurate information and useful results. Attempting to overcome a widespread 'methodological nationalism' and accounting for the different levels in which policy is entangled represents a useful way to ensure an adequate and well-rounded conceptualisation and analysis of the research object (Dale and Robertson, 2009). 
While data on socioeconomic conditions, welfare, labour markets, and education and training systems is available at national and subnational levels for administrative units in almost all countries, the use of these units in research presents limitations. Functional relations, which are vital to understanding socioeconomic phenomena, are likely to be cut out (Eurostat, 2010: 5) as administrative boundaries are the only basis for delineation. An alternative territorial unit for research is provided by FRs. The next section discusses conceptual distinctions and introduces different types and usages of FR.

\section{FR: conceptual distinctions, types, usages}

The concept of FR refers to a subdivision of territories that results from the spatial differentiation and organisation of social and economic relations rather than to geographical boundaries, administrative particularities or to historical developments. FR denotes a relational delineation of space that does not necessarily 'reflect geographical particularities or historical events' (OECD, 2016b: 14) but is drawn with respect to 'spatial flows or interactions of various kind (persons, goods, material, energy, information, etc.)' (Klapka et al, 2013: 2). These functional flows or interactions 'are maximised within the region $[\ldots]$ and minimised across its borders'. While self-containment is seen as a defining the criterion of FRs, 'inner patterns of regionorganising interactions or flows' (Klapka et al, 2013: 3) can be used to classify differing types of FRs, including nodal flows.

The most common FRs are local labour market areas (LMAs) and functional urban areas (FUAs) (Klapka et al, 2013: 99). The delineation commonly relies on commuting patterns and aggregates smaller administrative units. So far, data on LMAs is only available on the basis of national statistics, but for several years Eurostat has been looking at whether 'these national LMAs are sufficiently comparable and could be used in a European context' (Eurostat, 2010: 5). FUAs consist of 'densely populated urban centres and adjacent municipalities with high levels of commuting (travel-to-work flows) towards the densely populated municipalities' (OECD, 2016a: 15). In this sense, FUAs are 'nodal regions' (Brown and Holmes, 1971) where the orientation of spatial flows or interactions are centred to or radiate from so-called 'nodes'.

In short, FRs offer a conceptual lens to grasp interactions and flows impacting the overall spatial coordination of labour, education, welfare and, not least, of policy-making. 


\section{Policy analysis across Europe's regions in the YOUNG_ ADULLLT project}

According to the overall objective of the YOUNG_ADULLLT research, each of the nine participating countries selected two FRs $(\mathrm{N}=18$, see Figure 2.1) to examine the LLL policies/measures chosen as case studies.

The underlying assumption is that regional/local peculiarities produce different skill ecologies, different types of networks and distinct patterns of policy-making, impacting life courses. The FR concept has been adopted on the basis of two related premises: first, LLL policies are highly context-specific and are therefore best understood in their regional/local context; second, the cultural meanings of policies are constructed by different stakeholders in relation to their implementation context and the configurations of actors. In this context FRs offer a major advantage over administrative units as the basis of comparison. The administrative and historical grounds for defining the latter vary widely from country to country, which makes comparability even in terms of population or area hard to achieve (Eurostat, 2010: 5). Moreover, normative regions are more likely to 'cut functional links that are vital to understand

Figure 2.1: Functional regions in YOUNG_ADULLLT

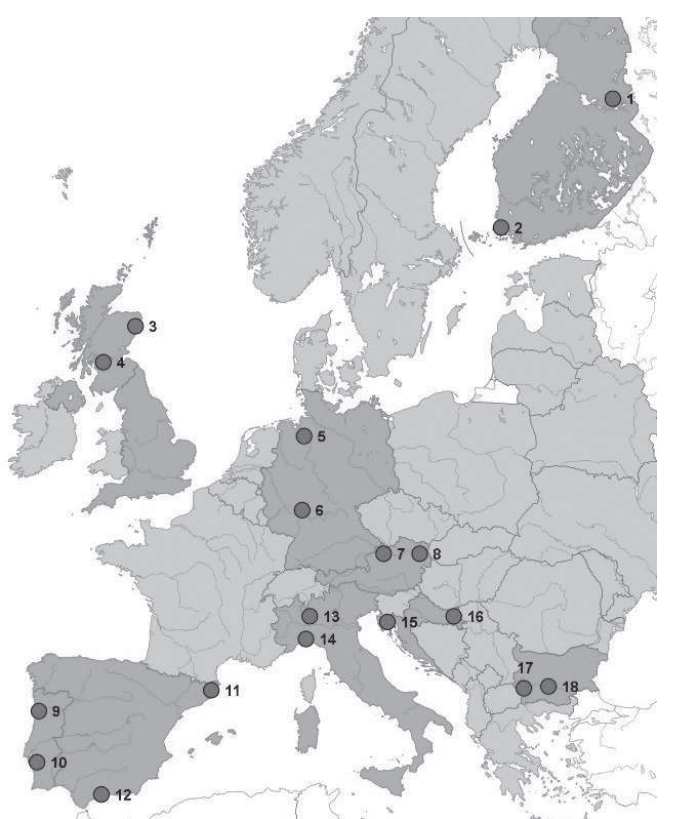

1 - Kainnu FR

2 - South-west Finland FR

3-Aberdeen City and Aberdeenshire FR

4- Glasgow City Region FR

5 - Bremen FR

6 - Rhein-Main FR

7 - Upper Austria FR

8 -Vienna FR

9 - Vale do Ave FR

10 - Litoral Alentejano FR

11 - Girona FR

12 - Malaga FR

13 - Milan FR

14 - Genoa FR

15 - Istria-County FR

16 - Osijek-Baranja County FR

17 - Blagoevgrad FR

18 - Plovdiv FR 
socioeconomic phenomena' (Eurostat, 2010: 5). FRs, on the other hand, as 'different, but comparable, territorial systems', should be seen as a starting point that affords a 'better understanding of the socioeconomic dynamics in place' (OECD, 2013: 72) and a rough idea of the relevant territory, which allows further data on the embeddedness of policies to be gathered subsequently.

The majority of FRs selected in YOUNG_ADULLLT were FUAs, with densely populated core(s) hosting a variety of employment opportunities, that account for strong linkages with the surrounding areas. In only a few cases were FRs located in (semi-)rural areas characterised by economic specialisations. Many of the selected FRs may be characterised as metropolitan areas consisting of multiple, linked urban cores, which are drivers for economic output, transportation hubs, and cultural and administrative centres. They account for a higher-than-average concentration of services and industries in countrywide comparison; however, the functional relations they display differ in terms of types and density of flows:

- Metropolitan areas especially display a high density of flows. Highly developed infrastructure renders commuting feasible. Examples in YOUNG_ADULLLT include: the two German metropolitan areas of Bremen (roughly 130,000 people commute every day to Bremen, Oldenburg and Bremerhaven) and Rhein-Main (a dense railway and motorway network used by roughly 350,000 commuters); the two Spanish FRs of Málaga (with its metropolitan transport consortium) and Girona (where the Area Public Transport Consortium facilitates geographical mobility within the region); Milan FR in Italy (railway and motorway systems allow people to commute to Milan to study or work); Vienna FR in Austria (180,000 people commute daily to Vienna); and the Bulgarian Plovdiv FR (the city attracts a workforce from a wider region, where more than 1.3 million people live).

- Some FRs are characterised by hubs for business and employment and play a particularly strong economic role in their national context. Examples are: Upper Austria FR (one of the principal centres of industrial production in Austria - particularly steel production and automotive supply); Aberdeen FR in Scotland; the two Bulgarian FRs of Plovdiv (it has a multi-sector economy providing around 7 per cent of the national sales revenue of goods and services) and Blagoevgrad (covering almost all sectors of the national economy).

- Some FRs offer well-established education and training infrastructures with a high concentration of schools and higher 
education institutions. In YOUNG_ADULLLT, several FRs are illustrative of this type: Spanish Girona FR (with its higher education district around the Universidad de Girona); Scottish Glasgow City (an important provider of higher educational opportunities on a national and increasingly international level, producing a third of Scotland's graduates); the two Bulgarian FRs of Plovdiv (of national importance with nine universities, 39,260 students and 78 primary, secondary and vocational schools with 8,351 pupils) and of Blagoevgrad (with two universities and three colleges); southwest Finland FR (with two universities in Turku - the capital city of the region - and four universities of applied sciences, as well as 75 post-compulsory educational institutions located throughout the region); Vienna FR in Austria (hosting nine public and four private universities, as well as a teacher training college, accounting together for 170,000 students in addition to another 13,300 students enrolled in the six universities of applied sciences).

- In other cases, an international harbour or airport is the "nodal point' of a FR, as such infrastructure offers important employment and business opportunities. Examples include: Genoa FR in Italy (a specialised container port to access trans-European and Mediterranean logistic corridors); the Portuguese Alentejo Litoral FR (the city of Sines has one of the biggest deep-water harbours in Europe); the German Rhein-Main FR (Frankfurt airport); and Spanish Málaga FR (Málaga airport).

- In a few cases, FRs are located in predominantly rural areas that display economic specialisations. Examples are: the two Portuguese FRs of Vale do Ave (agriculture, textile industries and logistics industries) and Alentejo Litoral (energy and logistics industries, alongside tourism and agriculture); the Finnish Kainuu FR (wood industry, bio economy and mining industry); and the two Croatian FRs of Istria County (manufacturing industry, tourism, trade, construction, real estate and business services) and Osijek-Baranja County (food-processing industry, cellulose production, paper, cardboard, crafts and trades).

Using FRs to contextualise the case studies contributed to capturing the different subnational realities in terms of education and training, welfare and the labour market. This focus on the specific regional/local landscapes of policy-making allowed the implementation and impact of LLL policies in the specific contexts of the 18 FRs to be analysed, identifying particular constellations of actors and interplays among individual, structural and institutional dimensions. This contributed 
to understanding whether and how policy makers, professionals and young people navigate the shifting geographies of LLL and how coordination might work. In the following sections, we provide two examples of how this was done and draw some conclusions on the usefulness of the FR concept in discussing coordinated policy-making in LLL.

\section{Coordinated policy-making: a glance at two FRs in Scotland}

Before we present and discuss the two Scottish FRs, it is worthwhile briefly discussing what coordinated policy-making entails. Coordinated policy-making denotes arrangements that successfully integrate labour market, social inclusion and individual life course aspects of policy formulation and implementation at regional and local level. Coordinated policy-making is viewed as an ideal-type sustainable institutional solution that takes account of all relevant actors, stakeholders, dynamics, trends and (mis)matches, avoiding redundancies and creating synergic effects in terms of integrating specific training or educational programmes with broader interventions for specific groups. It coordinates different areas of government (education, labour, economy) and facilitates the involvement of nongovernmental actors (business, training institutions, civil society) in the planning, regulation and provision of LLL opportunities in a particular territory.

In more conceptual terms, coordinating policy-making aims at accounting for the embeddedness of human action in institutional, economic, social, political and cultural conditions. Karl Polanyi ([1944] 1957) coined the term to point out the embeddedness of the economy in both economic and non-economic institutions. Later, Mark Granovetter (1985) viewed economic action as 'embedded in concrete, ongoing systems of social relations' (487) and argued that it is these social relations that help us explain outcomes. Embeddedness thus calls our attention to the cultural, cognitive and normative frames of reference, the patterns of (social) relationships, networks and infrastructures available to those aiming for the coordination of action. Thus, understanding how LLL policies relate to these various factors and conditions in a specific site allows us to discern key parameters for achieving better coordination in LLL policy-making.

The two cases examined in Scotland illustrate attempts to better coordinate policy-making in the field of LLL. Furthermore, they allow us to explore how concepts of embeddedness can inform our understanding of processes involved in coordinated policy-making in 
these FRs. In particular, the division of labour between policy levels as well as the city region deals are important elements conducive to coordinated policy-making, as will be further discussed.

In terms of political framing, the Scottish parliament has the role of devising and implementing social policy, and welfare, health, education and training, and youth policies, which are closely aligned to one another, reflecting the principles set out in the 'Christie Commission on the future delivery of public services' (Scottish Government, 2011). This reform of Scottish public policy placed an emphasis on partnership working between sectors and services to build public services 'around people and communities, their needs, aspirations, capacities and skills' (23). This holistic approach attempts to enhance policy articulation for greater coherence, impact and more effective use of resources.

National policies in Scotland are designed to operate in tandem to provide strategies to tackle national priorities. For example, the National Youth Work Strategy 2014-2019 (Scottish Government, 2014) contributes to education and skills policies, labour market policies and social policies, but also justice, health, sport, culture and equality policies. Policy enactment in Scotland adopts the so-called 'concordat approach', that is, regional and local policies are localised reflections of national policies, with national government devolving fiscal decisions and strategy prioritisation to local authorities. This system is supported and informed by national and local labour market intelligence and monitoring. This approach, however, also presents practical challenges for policy implementation regarding coordination and coherency among levels, sectors and actors. Within this Scottish context, the concept of FRs, or city regions as they are called in the UK, has played an increasingly important role in devolving national policies through to the regional and local levels.

City region deals are an agreement between the UK government, the Scottish government and member local authorities to create collaborative regional partnerships focused on improving regional economies. Each deal is bespoke to the city region and includes a range of measures designed to operate as a coherent whole. The concept is intended to involve member local authorities working together to combine their individual strengths and capacities. The city regions are also partly motivated by a desire to promote their capacity as entities to compete economically across the UK and internationally. The city regions are seen as the main engine of economic growth, being the market place for goods, services and employment, and centres of innovation and education as well as promoting social and 


\section{Coordinated policy-making in lifelong learning}

cultural activity. Since 2003, these city regions have been important for government in driving regeneration efforts and the implementation of major policy initiatives. The governance of a city region is coordinated at the regional level but is intended to allow an individual authority to maintain their own governance structures and local variation of policies in order to ensure local priorities are addressed. In Scotland, it is arguable that the city regions have a distinct nature compared to others in the wider UK in that, while operating to address regional issues and priorities, they can be seen as a key mechanism to implement national policies in contextualised ways. The two FRs selected for the UK component of YOUNG_ADULLLT were Glasgow FR and Aberdeen/Aberdeenshire FR.

\section{Glasgow City Region}

The Glasgow City Region's economic strategy was introduced in 2016, with a timetable running to 2030. This city region comprises of eight neighbouring councils: East Dunbartonshire, East Renfrewshire, Glasgow City Council, Inverclyde, North Lanarkshire, Renfrewshire, South Lanarkshire and West Dunbartonshire. Councillor Mark Macmillan (Leader of Renfrewshire Council), holder of the Cabinet's Enterprise Portfolio, stated that the establishment of the city region 'recognises the fact that the economies of the Glasgow City Region local authorities are completely interlinked' (Glasgow City Council, 2016, np). In addition to its economic objectives, the city region has a series of strategic social and health targets, including tackling social inequity. While there are some differences in the specific policyrelated strategies and projects across the city region, there is a level of coherence in the overarching policy strategies that cut across the overall region. The Glasgow City Region has interlinked local systems and economies, with distinctive social and economic characteristics and challenges. The collaborative responses include social, political and economic interactions among the partner councils and also with the wider UK and internationally.

The wider city region, which has a population of 1.75 million, plays a significant role in Scotland. Largely urban with some farming areas, the city region is an important provider of further and higher educational opportunities on a national and international level and there are important commuter flows from Argyll and Bute, Ayrshire, Stirling and the Edinburgh City Region. A large proportion of the population, particularly in the Glasgow city area, suffers income deprivation compared to Scotland as a whole. Despite the range of 
challenges, it is reported that the partnership of councils involved have, since 2003, contributed to notable positive economic impacts. A particular challenge for the region has been to widen participation in the labour market, tackle skills gaps in trades and consumer services as well as sustaining recruitment in social care, tourism and construction sectors. These challenges have strategic implications for the region's colleges as key providers of vocational education and training (VET) (SDS, 2016a).

\section{Aberdeen city and Aberdeenshire}

In 2008, the Strategic Development Planning Authority (SDPA) was formed to provide a partnership between Aberdeen city and Aberdeenshire councils to guide development over a 25-year period and establish a European city region. At the time of our analysis, this city region had above-average incomes and relatively low unemployment. However, there has been an economic downturn in the oil industry and resulting job losses. In addition, there are local differences in wealth and opportunity between some of the region's communities. The city region's SPDA aims to tackle these and other challenges in order to enhance employment and quality of life for residents as well as reducing reliance on locally dependent oil and gas jobs. This will include placing an emphasis on communities, public sector organisations and private businesses within a holistic strategy for renewal and development.

Aberdeen is Scotland's third-largest city and the regional centre for employment, retail, culture, health and higher education as well as the region's transport hub. The wider city region has prioritised areas in need of regeneration and includes coastal communities of north and south Aberdeenshire as well as parts of Aberdeen city with social, economic and area-based regeneration initiatives to improve the economy, environmental quality, accessibility, employment opportunities and the competitiveness of business.

There is a functional interdependency between Aberdeenshire and Aberdeen city (Lindsay, 2012) and a high percentage of trade apprenticeships in the two councils. At the time of our analysis, Aberdeenshire ranked third in Scotland for share of working age population with apprenticeship credentials. The Skills Development Scotland's (SDS) Regional Skills Analysis (RSA) report on the Aberdeen/Aberdeenshire skills-related developments over 2014-15 (SDS, 2016b) highlighted that while the city region has been successful since the 2008 crisis: 
There remains ... a challenge for the supply of skills to match demand ... The new City Deal investment promises further demand for construction and related skills in what has already been a tight labour market ... There continues to be a need to focus on diversifying the employment base, and increasing exports, including sector expertise, to reduce reliance on locally dependent oil and gas jobs. The supply of regional skills should help support this process. (SDS, 2016b: 18)

Therefore, while the Glasgow City Region faces greater challenges regarding employment and skills issues, Aberdeen/Aberdeenshire is undergoing rapid economic changes, exacerbated by the downturn in the crude oil market that will require particular policy and practice responses regarding the development of LLL and skills.

In the remaining part of this section, the Community Benefit Clauses (CBCs) policy will be discussed as an example of coordinated LLL policy-making.

The Scottish FRs feature policies developed across the member regions, providing appropriate case studies to illustrate the usefulness of the FR concept in understanding coordinated LLL policy-making. A key example is the CBCs policy. It requires those contracted by local government to contribute to delivering wider benefits in addition to the core purpose of a contract where a procuring organisation is given a contract valued at $f 4$ million or above. These can be used to support local councils' priorities including provision of LLL, skills and employability services. This particular regional/local policy addresses a range of social, economic and educational priorities and helps facilitate the building of infrastructure via funding and support obtained through these requirements.

CBCs are intended to facilitate not only economic growth but also wider social benefits and development. For example, the funding and contributions from contractors help provide targeted training and employment opportunities and educational support initiatives.

CBCs create economic, social or environmental obligations for the delivery of City Deal contracts to ensure that the benefits delivered are aligned to addressing the key economic priorities for the region.

The CBC policy builds on existing practices across the city region authorities to deliver community benefits and is intended to encourage connections between businesses and their communities. It can be argued that this arrangement fosters a sense of social responsibility and engagement for those businesses involved. 
The CBC policy is a strong illustration of regional/local manifestation of the Scottish policy framework and stance that advocates partnership and collaboration in order to deliver effective implementation of aligned policies as well as best value for money. The governance and planning of this policy involves: community planning, education services, land and environmental services, legal services and social work services. This policy, therefore, reflects the Scottish collaborative and aligned approach to implementation and monitoring of policies. In principle, this policy framework is intended to help grow the regional and local economy, including the delivery of sustainable employment outcomes for residents. This policy is also meant to help provide resources to address social inequality in communities, which is seen by the government as integral to promoting economic growth. Indeed, the Scottish government has produced its own case studies and independent research demonstrating the effectiveness of CBSs (Sutherland et al, 2015) and the policy's articulation with the National Performance Framework (MacFarlane and Cook, 2008). This research indicated that, overall, this policy has made a positive contribution to targets relating to job opportunities, apprenticeships, work placements and training for priority groups (Sutherland et al, 2015: iii). However, there is variation in the effectiveness of individual contracts and the additionality and sustainability of the CBCs outcomes has been more difficult to calculate because procuring organisations have not typically required their contractors to monitor these aspects (Sutherland et al, 2015). This is interesting given that the original city region plans for the CBCs intended that the benefits included as contractual obligations should be monitored as part of the tender process and successful suppliers are required to provide regular monitoring information outlining the $\mathrm{CBC}$ delivery progress. Interviews conducted for the YOUNG_ADULLLT research indicated that there was also variance in actual monitoring data at local council level, sometimes because councils were reluctant to enforce businesses' honouring of their contractual commitments for fear of losing their support and involvement in their community.

While there are similarities in how the CBC policy has been implanted, it is important to note that the research revealed that the LLL and skills policy enactment at the regional level is taking different routes. In the Aberdeen FR, many of these policies are being used to support young adults in transitioning to VET or apprenticeship schemes. In Glasgow FR, the support is mainly directed towards supporting disadvantaged young adults to overcome barriers (e.g. financial, health, family situations) to get back into education, training, 
employment or volunteering. Indeed, the Glasgow FR stands out in our research as in only one other FR (south-west Finland FR) are other, more holistic purposes (i.e. social inclusion, self-esteem, mental health) explicitly evident in regional policies. Historically, policies and material actions in the Aberdeen FR have been more focused on providing opportunities that encourage economic development and create new employment in a range of areas that are appropriate and attractive to the needs of different industries, but with a particular focus on the energy sector.

It can be argued, therefore, that localised expression of the CBC policies and resulting opportunities for young adults are strongly related to the socioeconomic context of each region. This context also shapes the range of partners seen as required to enact the policies and actions intended to tackle LLL skills challenges. The scale of disadvantage and related issues has meant that in the Glasgow FR the nature of partnerships has developed to reflect the complexity and interrelated nature of the issues, and includes a diverse range of public, third sector and private organisations. In Aberdeen FR, historically, there has been less disadvantage, higher levels of employment and greater success in attracting youth with high skills levels. However, in recent years, volatility in the energy market has raised questions about the regional skills strategy. Subsequently, the policy actors and partnerships have had to realign and refocus to better support workers who were made redundant. Previously, the main skills actors influencing local policy and strategies were the oil and gas sector employers. Now, however, market uncertainty and its impact on employment and related social issues has seen public, private and third sector actors emerge as key partners, as efforts to achieve the policies are seen to require a more diverse and holistic approach.

As previously stated, using the FR as a unit of analysis in YOUNG_ ADULLLT enables a contextualised focus on regional/local LLL policies, such as the CBC. This facilitates a nuanced understanding of how these policies are enacted from national to local level. It also highlights, especially in the Scottish FR case studies, how the LLL policy process involves numerous interconnected actors and complex vertical and horizontal systems of governance and relational and power dynamics. However, there are particular concepts that can further inform our understanding of how these interconnected actors influence the LLL policy process within the FR. 


\section{Discussion - FRs as dynamic units: coordinated policy- making in LLL}

Ongoing processes of globalisation, internationalisation and Europeanisation have challenged the ways we conceptualise and analyse policy-making, questioning in particular the usefulness of static and absolute spatial concepts such as that of the nation or region. FR emerges here as a potential dynamic concept with which to understand context- and culture-specific aspects of the policy-making process, as was previously argued.

The two Scottish FRs reveal the interplay between the economy, society, the labour market and education systems. Local priorities and conditions shape not only the focus and nature of the policy enactment but also the range of actors involved. Organisational relationships, while similar in each FR, are shaped by the national and local policy environment, and also influence that environment. For this reason, the theory of embeddedness (Polanyi, [1944] 1957) is relevant and assists our understanding of how these conditions influence the arrangement and activity of the various policy actors. The economic environment clearly shapes the government's priorities and design of policies. However, we find that at regional and local levels, the nature of the resulting material actions and the configuration of local policy-related actors that enact, govern and monitor these policies do not simply reflect an external logic. If a purely economic/market-driven logic or an ideological policy stance was paramount then we would expect to see the policy structures, institutions and their actors arranged and operating in a uniform fashion. However, the nuanced enactment of the CBC policy, and indeed other national policies in Scotland, such as Developing the Young Workforce, illustrates the importance of taking into account the interpretation of context by actors. These actors interrelate and collaborate at different levels, each with varied degrees of influence, power, knowledge and resources. This 'lifeworld' as Habermas (1981) would call it, shapes the actual policy actions and their consequences.

An economic sociological perspective, such as that of Polanyi, therefore, is particularly apposite considering how the regional and local policy actors and institutions are not only influenced by context but influence each other through their relational networks. This is not to ignore or negate the structural impact of economic forces on systems but rather to understand how systems respond to such contexts. To do so, we must take into account the complex social relationships and agency of actors involved at all levels. 
We would argue, therefore, that the Scottish examples discussed in this chapter demonstrate the usefulness of the FR concept in understanding coordinated policy-making in the field of LLL, and that certain concepts, such as Polanyi ([1944] 1957) and Granovetter's (1985) thinking on embeddedness, provide valuable analytical frameworks to understand the detailed processes involved. These FRs illustrate how systems that are designed at a national level use coordinated partnership with the intention of translating these policies to suit regional and local needs. Such partnership and devolved policy enactment are key principles of current Scottish policy and require interrelated vertical and horizontal collaborative networks.

At regional and local levels, the principles of the partnership approach have guided coordination between governmental and nongovernmental actors. These principles can be found in the 'Christie Commission on the future delivery of public services' (Scottish Government, 2011) and guide partners to work in collaboration as a means of promoting efficient delivery of policies at all levels. The complex nature of Scottish policy requires particular governance approaches across sectors, departments and among the various actors involved. The Scottish government has been devolving responsibility for enacting LLL policies and related actions to regional and local partnership structures including public, private and third sector actors. Scottish LLL policies ultimately rely on effective local partnership for enactment and impact. Such partnership working is seen by policy makers as promoting better alignment of services to support individuals' and employers' needs and more effective sharing of information to facilitate pathways into employment.

The governance and organisation of the enacted policies and material actions are similar in our two examples of FRs, with regional and local partnership boards providing strategic management and monitoring. Local authorities prepare local development plans that cover a wider range of issues in more detail. Also at the local level, Community Planning Partnerships (CPPs) play a key role and involve a range of public, private and third sector partners. They use their respective local authority Single Outcome Agreements with government to help identify priorities for LLL and deploy appropriate actions.

The recommended representation of key stakeholder groups such as employers, the third sector, national agencies and local government on regional management groups and local CPPs should, in principle, facilitate communication and sharing of information and ideas to effectively guide the strategies. However, there is a lack of evidence on whether the differing stakeholders work effectively together. 
Where governance was reported to be more effective and coherent, stakeholders highlighted the role of good relationships and the presence of historical networking in qualitative feedback from Aberdeen/ Aberdeenshire policy representatives during the YOUNG_ADULLLT research.

There are also issues regarding representation of the public in the governance of the city regions. An online research paper from Policy Scotland stated: 'If City Deals are to be made more inclusive, individuals, businesses and communities need to be empowered to participate in and contribute towards how deals are formed and delivered' (Waite et al, 2017: 1). This highlights the importance of participation of all actors in the decision-making processes of the city regions.

Examination of the Scottish FR illustrations moves our understanding of policy enactment beyond a purely spatial and stratified understanding to one that allows recognition of the relational aspects. While the national policy rhetoric extols the importance of partnership working and devolved decision-making to address local priorities, it is arguable that the policy process in the Scottish FRs actually reveals an increasingly centralised system of monitoring and accountability to steer and assess this so-called devolved process. Indeed, policy documentation reveals an increase in central monitoring of partnerships' progress against the strategic targets through national data systems and outcomes-based accountabilities.

Jessop (1997) writes about the regionalisation process and denationalisation of the state, where the activities of the state are dispersed. While this is evident in England, in Scotland we see a more complex process, where regionalisation is framed by the government's centralist concern with ensuring the integrity of national policy. Since the economic crisis, there has been an increase in the collection and use of data on key performance indicators to support the monitoring of progress at local and regional levels by national authorities. For example, the Opportunities for All policy (2012) sets out the requirement for tracking and monitoring individuals as they move through the learning system. In the Developing the Young Workforce project (2014), there are specific outcome-based targets for local authorities, schools, colleges and employers across the seven-year duration of the policy.

Therefore, the policy spaces in the Scottish model, including the FRs and their constituent sub-spaces, can be seen to be comprised of vertical and horizontal relational networks, pathways and partnerships. Here Jessop's (2016) concepts are helpful in understanding why 
policy systems are a tangle of networked relations. Theorists such as Lefebvre ([1978] 1991) and Harvey (2006) add that these partnerships are dynamic and stress the importance of relationships among the various actors and their production of ideas and activities.

It is also important to recognise that spaces such as FRs are a manifestation and arena of politics and power. Here the ideas of Doreen Massey are helpful. The social relationships present in networks and partnerships constitute a 'geometry of power' (Massey, 1994: 4). Such spaces are socially produced at various scales and not fixed. Rather, they are dependent upon what networks and actors are present.

In closing, FRs are seen by government and local policy actors as ways to organise and govern policy enactment. The concept of FRs, if they recognise power dynamics present, can be extremely helpful in understanding policy enactment processes including LLL. Rather than fetishising space, we are able to use the FR concept to go beyond the descriptive and explore, within this construct, relational networks with their integral 'power, projects and politics' (Robertson, 2009: 2).

\section{References}

Brenner, N. (1999) 'Globalisation as reterritorialisation: The re-scaling of urban governance in the European Union', Urban Studies, 36(3): 431-51, available from: https://doi.org/10.1080/0042098993466

Brenner, N. (2004a) New State Spaces: Urban Governance and the Rescaling of Statehood, Oxford: Oxford University Press.

Brenner, N. (2004b) 'Urban governance and the production of new state spaces in Western Europe, 1960-2000', Review of International Political Economy, 11(3): 447-88, available from: https://doi. org/10.1080/0969229042000282864

Brown, L. A. and Holmes, J. (1971) 'The delimitation of functional regions, nodal regions, and hierarchies by functional distance approaches', Journal of Regional Science, 11(1): 57-72.

Castells, M. (2009) The Rise of the Network Society: The Information Age: Economy, Society, and Culture (2nd edn), Malden, MA: WileyBlackwell.

Castree, N., Kitchin, R. and Rogers, A. (eds) (2013a) 'Place', in $A$ Dictionary of Human Geography, Oxford: Oxford University Press, available from: http://www.oxfordreference.com/view/10.1093/ acref/9780199599868.001.0001/acref-9780199599868-e-1399? rskey $=$ EQ $0 I r 1 \&$ result $=1400$ 
Castree, N., Kitchin, R. and Rogers, A. (eds) (2013b) 'Space', in $A$ Dictionary of Human Geography, Oxford: Oxford University Press, available from: http://www.oxfordreference.com/view/10.1093/ acref/9780199599868.001.0001/acref-9780199599868-e1744 ? rskey $=$ rBfKG0\&result $=1745$

Castree, N., Kitchin, R. and Rogers, A. (eds) (2013c) 'Territorialization', in A Dictionary of Human Geography, Oxford: Oxford University Press, available from: http://www.oxfordreference.com/view/10.1093/ acref/9780199599868.001.0001/acref-9780199599868-e1864 ? rskey $=\operatorname{trbg} 0$ O\&result $=1863$

Dale, R. and Robertson, S. (2009) 'Beyond methodological "ISMS" in comparative education in an era of globalisation', in R. Cowen and A. Kazamias (eds) International Handbook of Comparative Education, Dordrecht: Springer, pp 1113-27.

Dye, T. R. (2017) Understanding Public Policy (15th edn), Boston, MA: Pearson.

Eurostat (2010) European Regional and Urban Statistics Reference Guide, Luxembourg: Publications Office of the European Union.

Glasgow City Council (2016) 'A new name and a new economic strategy for the Glasgow City Region', 16 February, available from: https://www.glasgow.gov.uk/index.aspx?articleid=19100

Granovetter, M. (1985) 'Economic action and social structure: The problem of embeddedness', American Journal of Sociology, 91: 481-510.

Habermas, J. (1981) Theorie des kommunikativen Handelns, Frankfurt am Main: Suhrkamp.

Harvey, D. (2006) 'Space as a keyword', in D. Harvey (ed) Spaces of Global Capitalism: A Theory of Uneven Geographical Development, London: Verso, pp 119-48.

Held, D. and McGrew, A. G. (2003) 'The great globalization debate: An introduction', in D. Held and A. G. McGrew (eds) The Global Transformations Reader: An Introduction to the Globalization Debate (2nd edn), Cambridge: Polity, pp 1-50.

Held, D., McGrew, A. G., Goldblatt, D. and Perraton, J. (1999) Global Transformations: Politics, Economics and Culture, Stanford, CA: Stanford University Press.

Jessop, B. (1997) 'Capitalism and its future: Remarks on regulation, government and governance', Review of International Political Economy, 4(3): 561-81.

Jessop, B. (2016) 'Territory, politics, governance and multispatial metagovernance', Territory, Politics, Governance, 4(1): 8-32. 
Klapka P., Halás M. and Tonev, P. (2013) 'Functional regions: Concept and types', 21 June, available from: https://is.muni.cz/do/econ/ soubory/katedry/kres/4884317/41725568/12_2013.pdf

Lefebvre, H. ([1978] 1991) The Production of Space, Oxford: Blackwell. Lindsay, D. (2012) 'The city-region concept in a Scottish context', $\mathrm{PhD}$ thesis, University of Glasgow, available from: http://theses.gla. ac.uk/3811/

MacFarlane, R. and Cook, M. (2008) 'Community benefits in public procurement: A report demonstrating the methodology for including targeted recruitment and training clauses in public sector contracts', Scottish Government and COSLA, available from: http://readyforbusiness.org/wp-content/uploads/2012/11/libscotgovcombenefitsinproc.pdf

Massey D. (1994) Space, Place and Gender, Cambridge: Polity Press.

McCarthy, J. (2007) 'Territoriality', in M. Bevir (ed), Encyclopedia of Governance, Thousand Oaks, CA: SAGE Publications, pp 959-60, available from: https://doi.org/10.4135/9781412952613.n532

OECD (Organisation for Economic Co-operation and Development) (2013) Rural-urban partnerships: An integrated approach to economic development. Paris: OECD, available from http://dx.doi.org/10.1787/ 9789264204812-en

OECD (Organisation for Economic Co-operation and Development) (2016a) OECD Regions at a Glance 2016, Paris: OECD.

OECD (Organisation for Economic Co-operation and Development) (2016b) Productive Regions for Inclusive Societies: OECD Regional Outlook 2016, Paris: OECD.

Parreira do Amaral, M. (2014) 'Globalisierung im Fokus vergleichender Forschung', in C. Freitag (ed) Methoden des Vergleichs: Komparatistische Methodologie und Forschungsmethodik in interdisziplinärer Perspektive, Opladen, Berlin, Toronto: Budrich UniPress Ltd, pp 117-38.

Polanyi, K. ([1944] 1957) The Great Transformation, Boston, MA: Beacon Press.

Robertson, S. (2009) “'Spatialising” the sociology of education: Standpoints, entry-points, vantage-points', in S. Ball, M. Apple and L. Gandin (eds) Handbook of Sociology of Education, London and New York: Routledge, pp 15-26.

Scottish Government (2011) 'Christie Commission on the future delivery of public services', Edinburgh, available from: https://www. gov.scot/Publications/2011/06/27154527/0

Scottish Government (2014) 'Developing the young workforce: Scotland's youth employment strategy, Edinburgh. 
SDS (Skills Development Scotland) (2016a) Glasgow Skills Assessment January 2016, Glasgow: SDA.

SDS (Skills Development Scotland) (2016b) Skills Assessment: Aberdeen City and Shire January 2016, Glasgow: SDA.

Sutherland, V., McTier, A., Glass, A. and McGregor, A. (2015) 'Analysis of the impact and value of community benefit clauses in procurement', University of Glasgow, available from: http://www. residentsalliancegroup.com/docs/scotgov3.pdf

Taylor, P. J. (1994) 'The state as container: Territoriality in the modern world-system', Progress in Human Geography, 18(2): 151-62, available from: https://doi.org/10.1177/030913259401800202

Waite, D., McGregor, A. and McNulty, D. (2017) 'Issues paper on City Deals and inclusive growth', University of Glasgow, available from: https://policyscotland.gla.ac.uk/city-deals-and-inclusive-growth/ 
"A good reference point for future work on policy document formulation and transition to implementation. A great contribution to international policy studies and comparative education."

Peter Mayo, University of Malta

Available Open Access under CC-BY-NC licence.

This comprehensive collection discusses topical issues

essential to both scholarship and policy making in the realm

of lifelong learning (LLL) policies and how far they succeed in

supporting young people across their life courses, rather than

one-sidedly fostering human capital for the economv

Examining specific vet diverse regional and local contexts

across Europe, this book uses original research to evaluate

differences in scope, approach, orientation and objectives.

It examines the embedding of LLL policies into the regiona

economy, the labour market, education and training svstems

and the individual life projects of young people, with a focus on

those in situations of near social exclusion

Marcelo Parreira do Amaral is Professor of International and

Comparative Education at the University of Münster, Germans

Siyka Kovacheva is Associate Professor of Sociology and Social Policy

at the Universitv of Plovdiv. Bulgaria

Xavier Rambla is Associate Professor at the Autonomous University

of Barcelona, Spain.
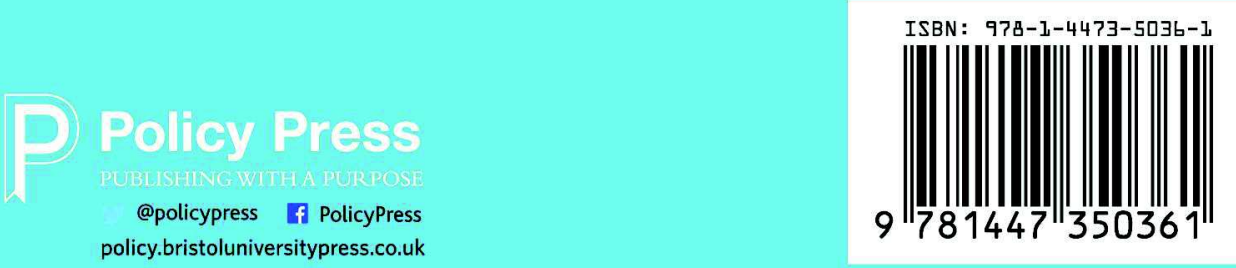